University of Nebraska - Lincoln

DigitalCommons@University of Nebraska - Lincoln

Faculty Papers and Publications in Animal

Science

Animal Science Department

December 2003

\title{
Evaluation of gene expression in pigs selected for enhanced reproduction using differential display PCR: II. Anterior pituitary
}

\author{
G. R. Bertani \\ University of Nebraska-Lincoln \\ C. D. Gladney \\ University of Nebraska-Lincoln \\ R. K. Johnson \\ University of Nebraska-Lincoln, rjohnson5@unl.edu \\ Daniel Pomp \\ University of Nebraska-Lincoln, dpomp1@unl.edu
}

Follow this and additional works at: https://digitalcommons.unl.edu/animalscifacpub

Part of the Animal Sciences Commons

\footnotetext{
Bertani, G. R.; Gladney, C. D.; Johnson, R. K.; and Pomp, Daniel, "Evaluation of gene expression in pigs selected for enhanced reproduction using differential display PCR: II. Anterior pituitary" (2003). Faculty Papers and Publications in Animal Science. 61.

https://digitalcommons.unl.edu/animalscifacpub/61

This Article is brought to you for free and open access by the Animal Science Department at DigitalCommons@University of Nebraska - Lincoln. It has been accepted for inclusion in Faculty Papers and Publications in Animal Science by an authorized administrator of DigitalCommons@University of Nebraska - Lincoln.
} 


\title{
Evaluation of gene expression in pigs selected for enhanced reproduction using differential display PCR: II. Anterior pituitary ${ }^{1}$
}

\author{
G. R. Bertani ${ }^{2}$, C. D. Gladney, R. K. Johnson, and D. Pomp ${ }^{3}$
}

Department of Animal Science, University of Nebraska, Lincoln 68583-0908

\begin{abstract}
The objective of this study was to identify differentially expressed genes in the anterior pituitary (AP) of sows selected for enhanced reproductive phenotypes. Selection in the Index (I) line was based on an index of ovulation rate and embryo survival, whereas random selection was used in the Control (C) line. Average numbers of fully formed piglets at birth were 12.5 \pm 1.5 and $9.9 \pm 2.0$ for Line $\mathrm{I}$ and $\mathrm{C}$ sows used in this study, respectively. In order to induce luteolysis and synchronize follicle development, sows were injected (i.m.) with $2 \mathrm{~mL}$ of prostaglandin $\mathrm{F}_{2 \alpha}$ analog between d 12 and 14 of the estrous cycle. Tissue was harvested $2 \mathrm{~d}(\mathrm{~d} 2)$ or $4 \mathrm{~d}(\mathrm{~d} 4)$ after injection, resulting in four experimental groups: $\mathrm{Cd} 2(\mathrm{n}=6), \mathrm{Cd} 4(\mathrm{n}=4), \operatorname{Id} 2(\mathrm{n}=$ $6)$, and Id4 $(\mathrm{n}=7)$. Differential display PCR (ddPCR)
\end{abstract}

was used to search for transcriptional changes between selection lines in the AP, using samples within line but pooled across days. Northern hybridization was used to confirm ddPCR results. For ddPCR, two pools were used from each line (C and I). Three genes were confirmed to be differentially expressed between Lines I and C: G-beta like protein, ferritin heavy-chain, and follicle stimulating hormone beta subunit, whereas many other expressed sequence tags were observed to be differentially expressed but still require confirmation. Our findings indicate that long-term selection to increase ovulation rate and decrease embryo mortality has altered transcriptional patterns in the anterior pituitary, most likely as correlated responses.

Key Words: Gene Expression, Pig, Pituitary, Reproduction, Selection

(C2004 American Society of Animal Science. All rights reserved.

J. Anim. Sci. 2004. 82:32-40

\section{Introduction}

Differential display PCR (ddPCR) was first described (Liang and Pardee, 1992) as a way of conducting gene expression studies by comparing eukaryotic messenger RNA (mRNA) levels from different sources. This technique enables the large-scale screening of the transcriptome without prior knowledge of existing information regarding sequence and identification of transcripts.

Gene expression analysis is a functional genomics approach that is useful for discovering novel expressed genes and for comparing mRNA levels of transcripts

\footnotetext{
${ }^{1}$ Published as paper No. 14089 of the Journal Series, Nebraska Agric. Research Division, Univ. of Nebraska, Lincoln 69583-0908. We thank S. Olberding, L. Messer, and M. Allan for their technical and laboratory assistance with this experiment. We are grateful to D. Chellen and D. Aherin for assistance with animal care, and R. Mandigo and C. Schrock for assistance with harvesting tissues.

${ }^{2}$ Scholarship funded by CAPES, Brazil. Researcher of Embrapa Swine and Poultry, Brazil.

${ }^{3}$ Correspondence: A218 Animal Science (phone: 402-472-6416; fax: 402-472-6362; e-mail: dpomp@unl.edu).

Received April 1, 2003

Accepted September 9, 2003
}

regulating fertility. The ddPCR method has been used for transcriptional analysis to understand reproductive processes in mouse (Lee et al., 2001; Minami et al., 2001), cow (Robert et al., 2001), human (Xu et al., 1999), Rhesus monkey (Ace and Okulicz, 1999), and pig (Li et al., 1996). Gene expression analysis is also useful for understanding the biological basis that underlies polygenic traits and the response to long-term genetic selection. Such traits as heat loss in mice (Allan et al., 2000) and reproduction in pigs (Gladney et al., 2004) have been investigated using ddPCR analysis in selection lines. These studies enabled the identification of a variety of differentially expressed genes, demonstrating that selection for polygenic traits can cause detectable changes in the transcriptome at various temporal and spatial coordinates related to the physiology of the trait.

The anterior pituitary is an important reproductive gland that intermediates communication between hypothalamus and ovaries. We investigated the effect of selection for enhanced reproduction on gene expression in the anterior pituitary of pigs. Differential display PCR was used to search for differences in transcription levels between lines, under the hypothesis that gene expression in the anterior pituitary gland of females has changed during the period of ovarian 
follicular development, as either a direct or correlated response to selection. Northern hybridization was used to confirm ddPCR results.

\section{Materials and Methods}

\section{Resource Population, Animals, and Treatments}

A general description of selection lines and sows used in this experiment is described in the companion article (Gladney et al., 2004) for a concurrent study evaluating the ovarian transcriptome. Briefly, 23 second-parity sows from the 16th generation of selection in the Index (Line I; $\mathbf{n}=13$ ) and Control (Line C; $\mathrm{n}$ =10) lines were used. Sows were checked daily after weaning for estrus, and the average weaning-to-estrus interval was $6.4 \pm 0.7 \mathrm{~d}$ for Line $\mathrm{C}$ sows and $8.9 \pm 4.4$ $\mathrm{d}$ for Line I sows. All sows from both lines were injected (i.m.) with $2 \mathrm{~mL}$ of the prostaglandin $\mathrm{F}_{2 \alpha}$ analog Lutalyse (Upjohn, Kalamazoo, MI) between d 12 and 14 after detection of estrus in order to induce luteolysis and synchronize follicle development. Anterior pituitaries from sows were harvested at $\mathrm{d} 2$ or $\mathrm{d} 4$ after Lutalyse injection, resulting in four treatment groups: Line C, d2 $(\mathrm{n}=6)$; Line C, d4 $(\mathrm{n}=4)$; Line I, d2 $(\mathrm{n}=$ $6)$; and Line I, d4 $(\mathrm{n}=7)$.

\section{Tissue Collection and RNA Extraction}

Sows were weighed before harvest. Anterior pituitary lobes were collected, within 20 min after stunning of the animal, by opening the cranial cavity, and the lobes were snap-frozen in a cryovial using liquid nitrogen. Tissues were stored at $-80^{\circ} \mathrm{C}$. The anterior pituitary was weighed before extraction of total RNA using Trizol LS (Gibco Life Technologies, Grand Island, NY). Poly(A) RNA was purified using the Qiagen (Valenica, CA) Oligotex mRNA midi kit. Total RNA and poly(A) RNA were quantified using the TD-700 fluorometer (Turner Designs, Sunnyvale, CA).

\section{Differential Display PCR (ddPCR)}

Differential display PCR (ddPCR) was used to search for differences in AP gene expression between lines, and Northern hybridization was used to validate selected ddPCR results. Two pools of poly(A) RNA (2.2 $\mathrm{ng} / \mu \mathrm{L}$ ) were used from each line, each having samples from one $\mathrm{d} 2$ sow and from one $\mathrm{d} 4$ sow. Pools were designated as CA and CB (Line C) and IA and IB (Line I). Although evaluation of line $\times$ day interaction would have been appealing, insufficient sample was available to afford adequate power for such an analysis.

Methods for ddPCR are described in the companion article (Gladney et al., 2004). Briefly, first strand complementary DNA (cDNA) synthesis was performed using $2.2 \mathrm{ng}$ of poly(A) and $4 \mathrm{pmol}$ anchor primer to a final volume of $10 \mu \mathrm{L}$. Template cDNA representing the four experimental groups were used for fluorescent
ddPCR employing 10 anchor primers combined with 20 arbitrary primers, resulting in a total of 200 different primer combinations and PCR reactions per sample pool.

\section{Evaluation of ddPCR Gels}

Products of ddPCR $(4 \mu \mathrm{L})$ were mixed with $1.5 \mu \mathrm{L}$ of loading buffer, denatured at $95^{\circ} \mathrm{C}$ for $5 \mathrm{~min}$, loaded in a 5.8\% polyacrylamide denaturing gel, and electrophoresed at $3,000 \mathrm{~V}(100 \mathrm{~W})$ and at $50^{\circ} \mathrm{C}$ for 2.5 to 5 h. Gels were dried and washed before scanning for fluorescence. Images were evaluated using Adobe (San Jose, CA) Photoshop 4.0 software. Analysis of banding patterns was based on subjective visual inspection, taking into account background intensities, consistency within pools of each line, and intensity of the differences between lines. A scoring system of 1 to 6 was used to rank and prioritize bands for further investigations, with score 1 representing marginal differences between selection lines and increasing values representing increasing robustness and consistency of differences. Selected bands were excised and placed in $50 \mu \mathrm{L}$ of TE buffer (10 mM Tris-Cl, $\mathrm{pH}$ 7.4), incubated at $37^{\circ} \mathrm{C}$ for $30 \mathrm{~min}$ and stored at $-40^{\circ} \mathrm{C}$.

\section{Reamplification, Cloning, and Sequencing}

Bands with scores of 5 and $6(\mathrm{n}=168)$ and a few bands with similar expression between lines $(\mathrm{n}=12)$ were sequenced $(n=179)$ as previously described (Gladney et al., 2004). Sequences were managed using BioEdit version 5.0.0 (jwbrown.mbio.ncsu.edu/BioEdit/bioedit.html). Expressed sequence tags (EST) were searched for similarity against the $\mathrm{nr}$ databases using the BLAST $\mathrm{nr}$ database (www.ncbi.nlm.nih.gov/ BLAST/). Threshold of the expected value used for significant similarity was less than 0.001 . Sequences were characterized regarding the presence of repetitive elements using RepeatMasker (repeatmasker.genome.washington.edu) and were submitted to GenBank (accession numbers BE231450 to BE231460, BE231489 to BE231492, BE241013 to BE241061, and BE344516 to BE344576). Sequences in GenBank were incorporated by TIGR (the Institute for Genomic Research) to help construct the Porcine Gene Index (www.tigr.org/tdb/tgi/ssgi).

\section{Northern Hybridization Validation of Gene Expression Differences}

Three EST with putative gene expression differences between selection lines were chosen for further validation of ddPCR results using Northern hybridization. Total RNA from the same animals used in the ddPCR was used to form pools for Northern blots. One pool of total RNA (15 $\mu \mathrm{g})$ was used for each line, representing equal amounts of RNA from two d2 sows and one $\mathrm{d} 4$ sow. The small number of EST confirmed with Northern analysis, and the use of RNA pooled across 
days in the validation process, were the necessary result of the very limited amounts of pituitary samples available.

Asymmetric PCR was utilized for probe preparation with $10 \mu \mathrm{L}$ of a specific PCR product, $0.012 \mu M$ arbitrary primer, $0.12 \mu M$ anchor primer, $5 \mathrm{U}$ of Taq polymerase (Promega, Madison, WI), $1 \times$ enzyme buffer, $1.5 \mathrm{~m} M \mathrm{MgCl}_{2}, 0.2 \mathrm{~m} M$ each d(C,G,T)TP, $0.006 \mathrm{mM}$ $\mathrm{dATP}$, and $1 \mu \mathrm{Ci}$ of $\left[\alpha-{ }^{32} \mathrm{P}\right] \mathrm{dATP}$ in a volume of $50 \mu \mathrm{L}$. The PCR mixture was incubated in a PTC-200 thermal cycler (MJ Research, Waltham, MA) as follows: initial denaturation for $2 \mathrm{~min}\left(94^{\circ} \mathrm{C}\right)$, followed by 41 cycles of $30 \mathrm{~s}$ at $92^{\circ} \mathrm{C}, 30 \mathrm{~s}$ at $60^{\circ} \mathrm{C}$, and $2 \mathrm{~min}$ at $72^{\circ} \mathrm{C}$, with a final extension period of $7 \mathrm{~min}$ at $72^{\circ} \mathrm{C}$. Probes were denatured and hybridized with membranes overnight at $42^{\circ} \mathrm{C}$. Membranes were washed and exposed to a PhosphoImager cassette (Molecular Dynamics, Sunnyvale, CA) and scanned in a PhosphoImager SF. The level of expression of the gene under investigation was quantified using the software ImageQuant version 3.3 (Molecular Dynamics). Membranes were then stripped by two successive washes at $95^{\circ} \mathrm{C}$ (20 min each) in a solution of $0.1 \times \mathrm{SSC}$ with $0.5 \% \mathrm{SDS}$, and probed with G3PD (glyceraldehyde-3-phosphate dehydrogenase) to normalize expression of the gene under investigation.

\section{Statistical Analysis}

Anterior pituitary weight was analyzed using the GLM procedure of SAS (SAS Inst. Inc., Cary, NC) with the model $\mathrm{Y}_{\mathrm{ijk}}=\mu+\mathrm{L}_{\mathrm{i}}+\mathrm{T}_{\mathrm{j}}+(\mathrm{LT})_{\mathrm{ij}}+\mathrm{BW}_{\mathrm{ijk}}+\mathrm{e}_{\mathrm{ijk}}$, where $\mathrm{Y}_{\mathrm{ijk}}$ is the response of sow $\mathrm{k}$ in line $\mathrm{i}$ injected with the prostaglandin analog on $\mathrm{d} \mathrm{j} ; \mu$ is the constant; Li is the effect of the ith line; $T_{j}$ is the effect of the $j$ th day of slaughter after prostaglandin analog injection; $\mathrm{LT}_{\mathrm{ij}}$ is the interaction between line and day; $\mathrm{B}$ is the regression on body weight, Wijk; and $e_{i j k}$ is the residual.

\section{Results}

\section{Anterior Pituitary Mass}

Weights of anterior pituitaries were significantly different $(P<0.01)$ between Control $(351.0 \mathrm{mg})$ and Index (453.8 mg) lines. No difference was observed between anterior pituitary weights at d $2(407.4 \mathrm{mg})$ and $\mathrm{d} 4(410.9 \mathrm{mg})$, and the line $\times$ day interaction was not significant. Body weights of sows were not different between lines or day of tissue collection (Gladney et al., 2004).

\section{Differential Display and Sequence Characterization}

A total of 372 bands was extracted from differential display PCR and assigned quality scores based on the prioritization system previously described. Bands scored as $5(\mathrm{n}=100)$ and $6(\mathrm{n}=68)$ amounted to $45.2 \%$ of the extracted bands. Examples of bands scored as
6 are in Figure 1. The majority of extracted bands originated from Index line samples $(n=246 ; 66.1 \%)$ based on stronger intensity. Some bands with similar expression between lines $(\mathrm{n}=12)$ were also cloned and sequenced.

From the 179 bands processed, sequences were obtained for 162 clones. Sequence analysis indicated that 125 of the $162(77.2 \%)$ anterior pituitary expressed genes characterized had distinct sequences, being either singletons or part of an EST cluster. Long interspersed elements, short interspersed elements, long terminal repeats, or DNA elements were found in $10.4 \%(13 / 125)$ of these, and simple repeats or sequences with low complexity were found in $4.8 \%$ (6/ 125). Table 1 displays information on 125 EST with their GenBank accession numbers and TIGR tentative cluster (TC) ID.

These EST represent clones with total or partial similarity to known genes $(\mathrm{n}=73 ; 58.4 \%)$, to genes with an uncharacterized biological function $(\mathrm{n}=43$; $34.4 \%)$, or are novel $(\mathrm{n}=9 ; 7.2 \%)$. Among the EST that matched sequences of known biological function, we observed EST related to mitochondrial function, signal transduction, splicing, endocrine activity, cell growth, and translation. Most (110 of 125) of the anterior pituitary EST are included in the TIGR Porcine Gene Index (March, 2003); 89 are clustered into $85 \mathrm{TCs}$, and 21 represent singletons.

\section{Northern Hybridization Validation of Gene Expression Differences}

Evaluation of gene expression using Northern hybridization was performed for the G-beta like protein, ferritin heavy-chain, and follicle stimulating hormone beta subunit genes. Differential expression of each gene was validated with line direction of expression changes in agreement with those observed in differential display. Results for two genes are presented (Figure 1). Signal observed for $G 3 P D$ control probe showed that similar amounts of RNA were loaded for each line (data not shown). Selection for the reproduction Index decreased expression relative to Line C (G-beta like protein and ferritin heavy-chain) by 56 and $42 \%$, respectively, and increased expression of follicle stimulation hormone beta subunit by $10 \%$.

\section{Discussion}

We employed a thorough differential display evaluation to identify gene expression changes in the female anterior pituitary as a result of long-term selection for increased ovulation rate and embryo survival. Many differentially expressed transcripts were identified and characterized, and a sample of these was confirmed using Northern hybridization (G-beta like protein, ferritin heavy-chain, and follicle stimulation hormone beta subunit). In general, the range of mRNA expression ratios observed was small, as might be ex- 


\section{Differential display}

\section{G-beta}

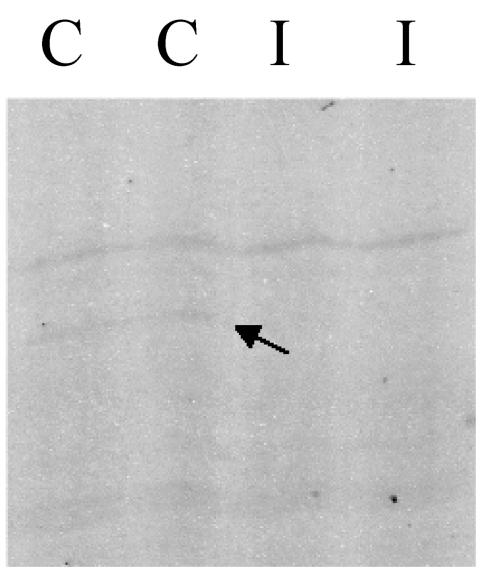

Ferritin HC

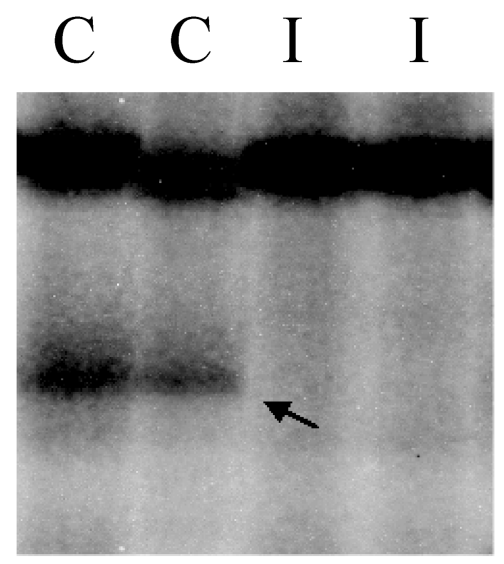

Northern

\section{G-beta Ferritin HC}

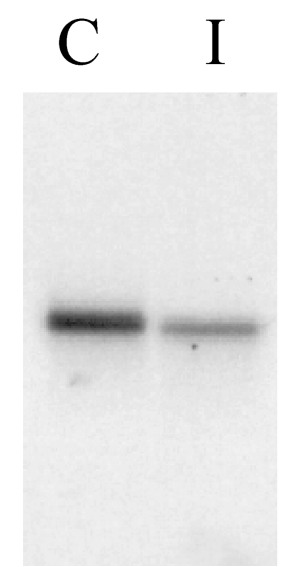

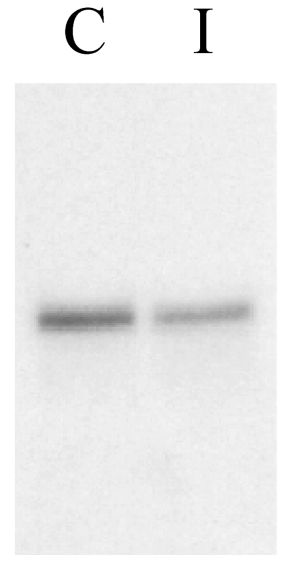

Figure 1. Differential display PCR and Northern hybridization results showing reduced expression (mRNA levels) of G-beta like protein and Ferritin heavy chain in anterior pituitaries of the Index selection line (I) relative to the Control line (C). Arrows point to the ddPCR bands that were excised from gels for sequence characterization. Two pools of samples were used to represent each line.

pected when evaluating selection response at the transcriptional level, and in agreement with a concurrent study using ovarian follicles (Gladney et al., 2004).

The Index line of pigs exhibits significant phenotypic improvements in ovulation rate and embryo survival (Johnson et al., 1999), which were the direct targets of selection. Increases in the number of pigs born alive have been partially limited to some extent by an increase in stillbirths (Johnson et al., 1999). Stillbirth in pigs can be caused by a variety of factors and has a genetic basis with several QTL localized in the Index and Control selection lines (Cassady et al., 2001). It has been suggested that iron deficiency is associated with an increased incidence of stillbirths in both pigs (Moore et al., 1965) and humans (Batu et al., 1972). Ferritin is a protein expressed in many tissues that plays an important role in iron storage and metabolism. Ferritin subunits (light and heavy chains) can be regulated at the transcriptional or translational levels (White and Munro, 1988). Ferritin Heavy Chain $(F T H)$ transcription can be increased by transcription factors (Bevilacqua et al., 1994), thyrotropin (Chazenbalk et al., 1990), and progesterone (Zhu et al., 1995).

A negative correlation exists in boars between ferritin and iron concentrations and testis size, associated with changes in FSH levels (Ford et al., 2001; Wise et al., 2003). Iron overload is a genetic condition in humans caused by a mutation in the hemochromatosis gene (HFE; Feder, 1999), which encodes a membrane protein that can form a complex with endogenous transferrin receptor (TfR; Ikuta et al., 2000). Mice that have had HFE knocked-out have the iron overload phenotype (Zhou et al., 1998). Iron overload can result in lower levels of circulating LH and FSH leading to hypogonadotropic hypogonadism (Cundy et al., 1993), probably due to iron deposition in pituitary cells impairing their function (Bergeron and Kovacs, 1978; Charbonnel et al., 1981). In contrast, boars with elevated testicular ferritin have elevated FSH secretion (Ford et al., 2001).

We demonstrate that selection for increased ovulation rate and embryo survival has decreased mRNA levels of FTH in the anterior pituitary of sows. Although no evidence exists for a link between reduced FTH and increased incidence of stillbirths, it is possible that alterations in iron homeostasis are involved. Alternatively, it has recently been demonstrated that $F T H$ is involved in the folate pathway by enhancing expression of serine hydroxymethyltransferase and de novo thymidine biosynthesis (Oppenheim et al., 2001). Supplementation of folic acid during gestation leads to increases in litter size, primarily due to improved embryo or fetal survival (Lindemann, 1993).

Expression of the follicle-stimulating hormone beta subunit $(F S H \beta)$ gene is up-regulated by selection for enhanced reproduction. This result is consistent with the role of FSH in regulation of ovarian follicle development (Hadley, 2000). Higher plasma levels of FSH have been found in both females and males (Cassady et al., 2000) from the Index line. Although large differences in allele frequencies were found for a genetic marker within the $F S H \beta$ locus between the Index and Control lines (Linville et al., 2001), influences of potential genetic drift were confounded with those results 
Table 1. GenBank accession numbers, the Institute for Genomic Research (TIGR) cluster information, gene identification, and direction of expression change between selection lines for anterior pituitary EST characterized in this differential display study

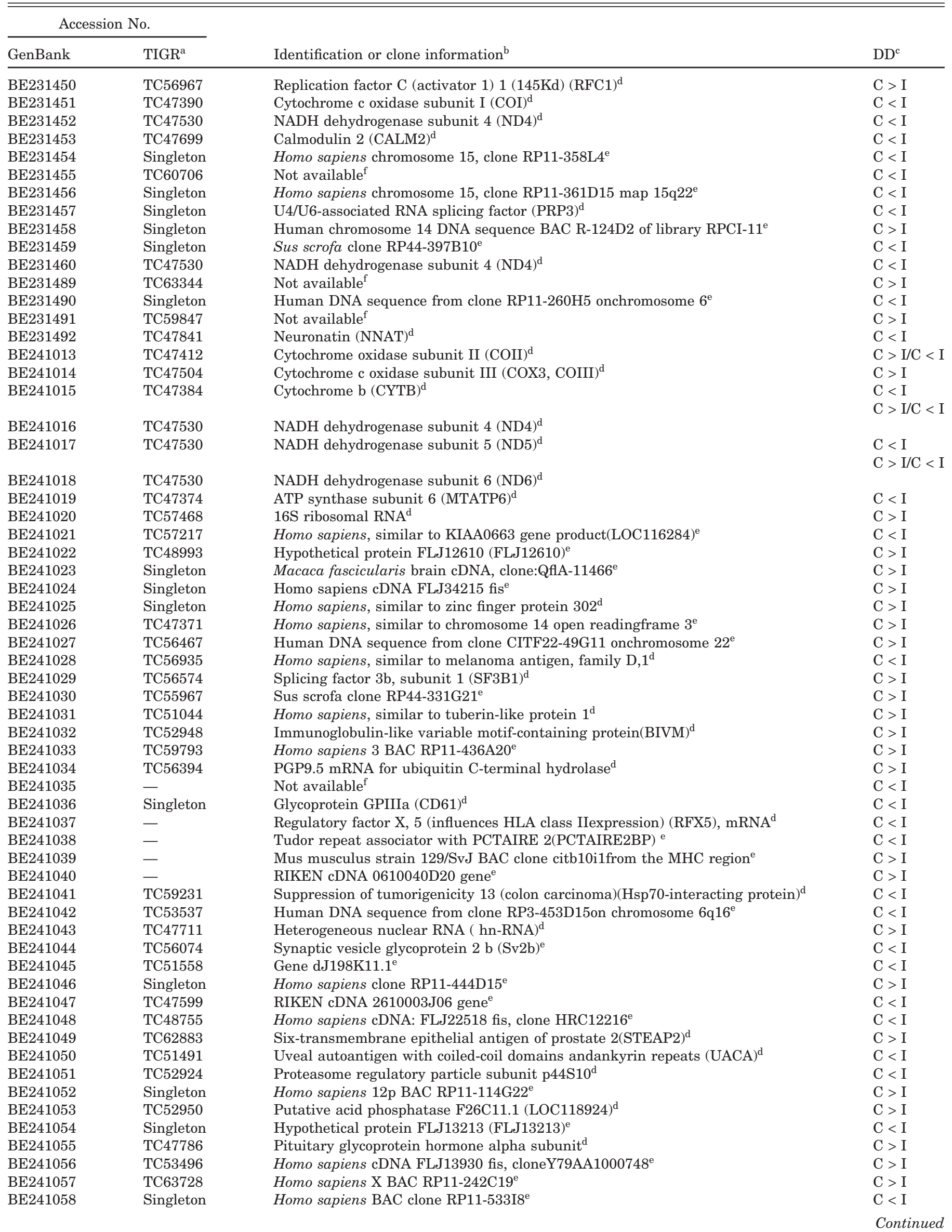


Table 1 (Continued). GenBank accession numbers, the Institute for Genomic Research (TIGR) cluster information, gene identification, and direction of expression change between selection lines for anterior pituitary EST characterized in this differential display study

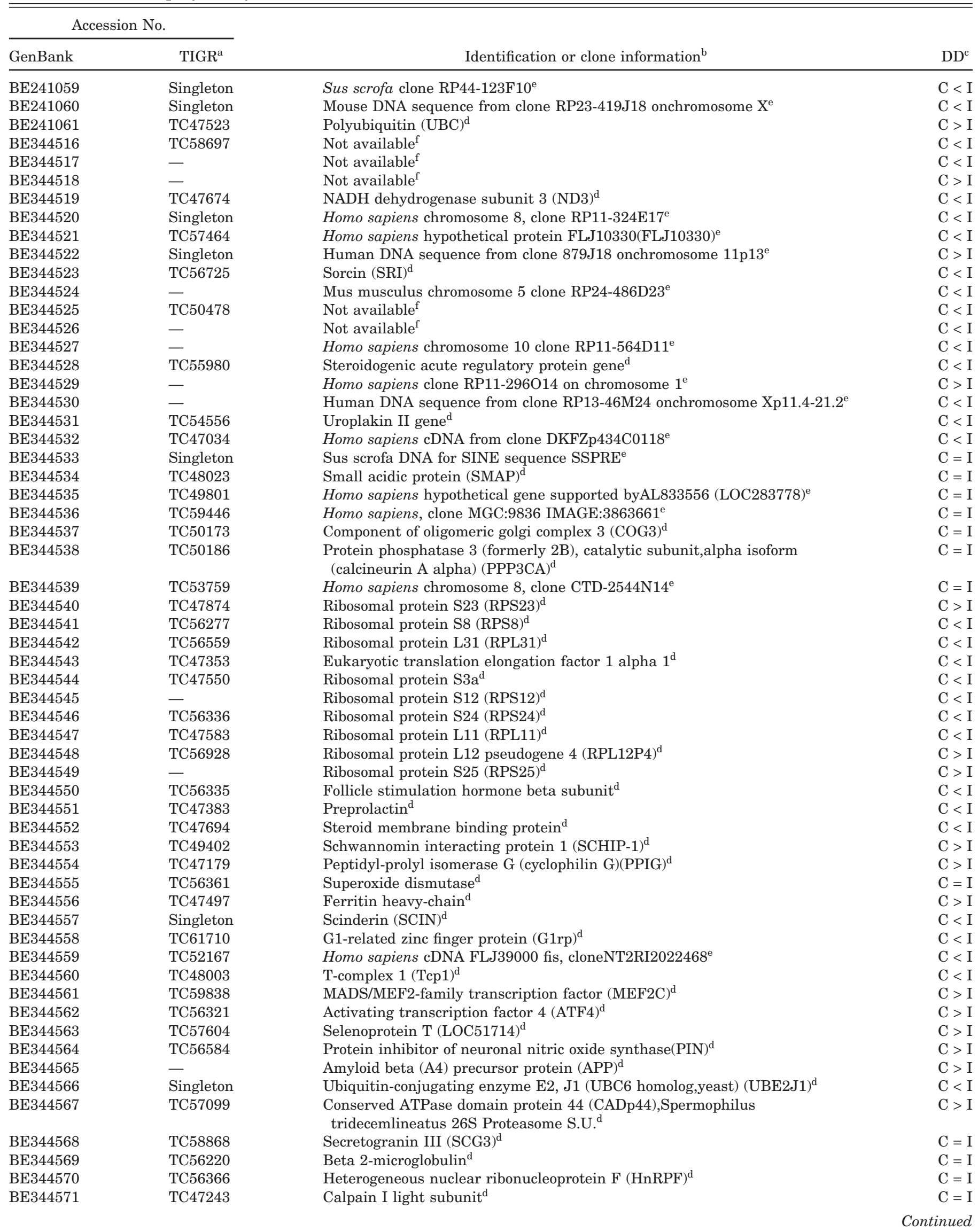


Table 1 (Continued). GenBank accession numbers, the Institute for Genomic Research (TIGR) cluster information, gene identification, and direction of expression change between selection lines for anterior pituitary EST characterized in this differential display study

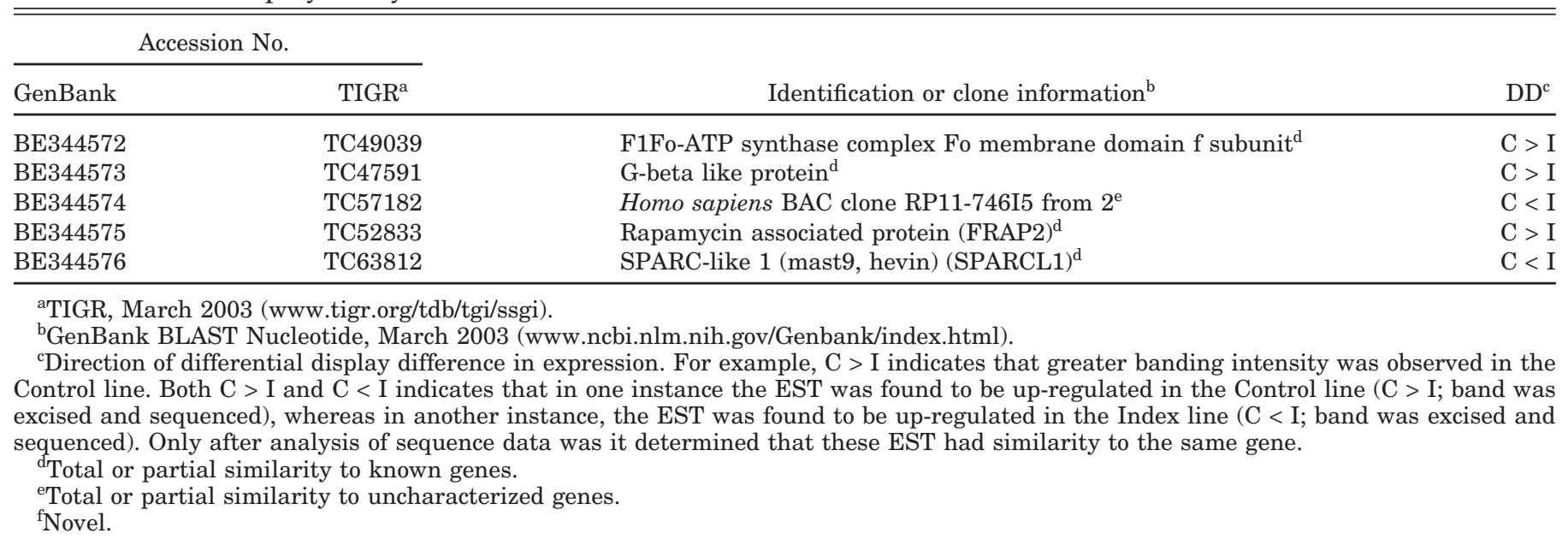

because the additive and dominance effects of the alleles did not differ from zero for any trait. Rohrer et al. (2001) identified several trans-acting QTL regulating plasma FSH levels in boars, but no evidence for a cisacting QTL within or near the $F S H \beta$ locus was found. In follicles of sows from the Index line, follistatin (FST) was found to be down-regulated (Gladney et al., 2004).

Taking into account these findings along with those of others studies conducted with these selection lines (Cassady et al., 2000), it is possible that low levels of follicular FST mRNA could be related to the elevated levels of $F S H \beta$ pituitary mRNA in the Index line. However, Schneyer et al. (2003) recently found that follistatin has lower affinity for activin B, the pituitary form, than for activin A, the ovarian form. Also, Li et al. (1998) determined that FST mRNA concentration in the pituitaries of boars is not associated with FSH secretion.

Levels of mRNA for the G-beta like protein transcript were lower as a response to Index selection. G-Proteins are coupled with different receptors, and the beta subunit can be coupled with alpha subunits, which could stimulate or inhibit a given signaling pathway (Garrett and Grisham, 1999). Given the potential involvement of G-beta like protein in many important physiological processes, it will be difficult to assign relevance to the down-regulation of this gene in the Index line until a global gene expression analysis is conducted and cluster analysis is performed.

A novel finding of this study was that selection for the reproductive Index led to significantly increased weight of anterior pituitary in sows. There may be a correlation between this finding and the fact that twice as many differentially expressed bands were isolated from Line I vs. Line $\mathrm{C}$, with the increased pituitary weight representing a physiological response to an increased metabolic demand in the Index line pituitary.

Many EST with known functions in reproductive physiology were isolated, including pituitary glycopro- tein hormone alpha subunit, steroidogenic acute regulatory protein, follicle stimulating hormone beta subunit, preprolactin, and steroid membrane binding protein. In addition, many EST with undefined functions or that are novel were isolated. Future characterization of this latter subset of genes may contribute to understanding the molecular architecture of litter size in swine.

In summary, selection for increased ovulation rate and embryo survival has acted in part by altering gene expression of many transcripts in the anterior pituitary during a period of follicular development. Concurrent alterations in the ovarian follicle transcriptome have also been identified in the same animals (Gladney et al., 2004). The use of gene expression analysis represents a new vista to dissect polygenic traits and the nature of long-term selection response in livestock species. Although many potentially significant gene expression differences were uncovered using ddPCR, only a small sample of these was confirmed using Northern hybridization due to limited availability of anterior pituitary samples. This limitation also led to pooling of results across the two time points of follicular development used in this study, potentially confounding temporal differences that may have existed between the selection lines. Further confirmation of differential expression on a larger scale, as well as a deeper analysis of the anterior pituitary transcriptome, will be made possible by future largescale expression profiling using microarrays.

Although application of transcriptional analysis to understanding selection response is a powerful tool, it is not possible to determine whether genes differentially expressed between selection lines represent QTL or the downstream consequences of QTL actions. The integrated approach of expression profiling in QTL mapping populations (e.g., Schadt et al., 2003a,b) would help determine the nature of transcriptional changes and their relationship to genetic variation 
that contributes to complex traits and long-term response to selection. Furthermore, such integration would help partition gene expression results into those that are true responses to selection and those that result from genetic drift.

\section{Implications}

Differential display PCR was used to analyze gene expression differences in anterior pituitaries between pigs selected for increased ovulation rate and embryo survival and pigs of a randomly selected control line. Combined with concurrent analysis of the ovarian follicle transcriptome, our results indicate that a large number of gene expression changes may be involved in long-term selection response for a complex trait such as reproduction. Several individual gene expression changes were confirmed and present novel insights into pathways regulating reproductive phenotypes and the nature of the genetic architecture of complex traits with low heritability such as ovulation rate.

\section{Literature Cited}

Ace, C. I., and W. C. Okulicz. 1999. Identification of progesteronedependent messenger ribonucleic acid regulatory patterns in the rhesus monkey endometrium by differential- display reverse transcription-polymerase chain reaction. Biol. Reprod. 60:1029-1035.

Allan, M. F., M. K. Nielsen, and D. Pomp. 2000. Gene expression in hypothalamus and brown adipose tissue of mice divergently selected for heat loss. Physiol. Genomics 3:149-156.

Batu, A. T., U. Hla-Pe, T. Than, and K. K. Nyunt. 1972. Iron deficiency in Burmese population groups. Am. J. Clin. Nutr. 25:210-217.

Bergeron, C., and K. Kovacs. 1978. Pituitary siderosis. A histologic, immunocytologic, and ultrastructural study. Am. J. Pathol. 93:295-309.

Bevilacqua, M. A., M. C. Faniello, T. Russo, F. Cimino, and F. Costanzo. 1994. Transcriptional regulation of the human $\mathrm{H}$ ferritin-encoding gene (FERH) in G418-treated cells: role of the Bbox-binding factor. Gene 141:287-291.

Cassady, J. P., R. K. Johnson, and J. J. Ford. 2000. Comparison of plasma FSH concentration in boars and gilts from lines selected for ovulation rate and embryonal survival, and litter size and estimation of (co)variance components for FSH and ovulation rate. J. Anim. Sci. 78:1430-1435.

Cassady, J. P., R. K. Johnson, D. Pomp, G. A. Rohrer, L. D. Van Vleck, E. K. Spiegel, and K. M. Gilson. 2001. Identification of quantitative trait loci affecting reproduction in pigs. J. Anim. Sci. 79:623-633.

Charbonnel, B., M. Chupin, A. Le Grand, and J. Guillon. 1981. Pituitary function in idiopathic haemochromatosis: Hormonal study in 36 male patients. Acta Endocrinol. 98: 178-183.

Chazenbalk, G. D., H. L. Wadsworth, and B. Rapoport. 1990. Transcriptional regulation of ferritin $\mathrm{H}$ messenger RNA levels in FRTL5 rat thyroid cells by thyrotropin. J. Biol. Chem. 265:666-670.

Cundy, T., J. Butler, A. Bomford, and R. Williams. 1993. Reversibility of hypogonadotrophic hypogonadism associated with genetic haemochromatosis. Clin. Endocrinol. 38:617-620.

Feder, J. N. 1999. The hereditary hemochromatosis gene (HFE): a MHC class I-like gene that functions in the regulation of iron homeostasis. Immunol. Res. 20:175-185.
Ford J. J., T. H. Wise, D. D. Lunstra, and G. A. Rohrer. 2001. Interrelationships of porcine $\mathrm{X}$ and $\mathrm{Y}$ chromosomes with pituitary gonadotropins and testicular size. Biol. Reprod. 65:906-912.

Garrett, R. H., and C. M. Grisham. 1999. Biochemistry. Saunders, Essex, England.

Gladney, C. D., G. R. Bertani, R. K. Johnson, and D. Pomp. 2004. Evaluation of gene expression in pigs selected for enhanced reproduction using differential display PCR and human microarrays: I. Ovarian Follicles. J. Anim. Sci. 82:17-31.

Hadley, M. E. 2000. Endocrinology. Prentice Hall, Upper Saddle River, NJ.

Ikuta, K., Y. Fujimoto, Y. Suzuki, K. Tanaka, H. Saito, M. Ohhira, K. Sasaki, and Y. Kohgo. 2000. Overexpression of hemochromatosis protein, $\mathrm{HFE}$, alters transferrin recycling process in human hepatoma cells. Biochim. Biophys. Acta 1496:221-231.

Johnson, R. K., M. K. Nielsen, and D. S. Casey. 1999. Responses in ovulation rate, embryonal survival, and litter traits in swine to 14 generations of selection to increase litter size. J. Anim. Sci. 77:541-557.

Lee, K. F., J. F. Chow, J. S. Xu, S. T. Chan, S. M. Ip, and W. S. Yeung. 2001. A comparative study of gene expression in murine embryos developed in vivo, cultured in vitro, and cocultured with human oviductal cells using messenger ribonucleic acid differential display. Biol. Reprod. 64:910-917.

Li M. D., G. J. Macdonald, T. Wise, and J. J. Ford. 1998. Positive association between expression of follicle-stimulating hormone beta and activin betaB-subunit genes in boars. Biol. Reprod. 59:978-982.

Li, M. D., R. L. Matteri, G. J. Macdonald, T. H. Wise, and J. J. Ford. 1996. Overexpression of beta-subunit of thyroid-stimulating hormone in Meishan swine identified by differential display. J. Anim. Sci. 74:2104-2111.

Liang, P., and A. B. Pardee. 1992. Differential display of eukaryotic messenger RNA by means of the polymerase chain reaction. Science 257: 967-971.

Lindemann, M. D. 1993. Supplemental folic acid: A requirement for optimizing swine reproduction. J. Anim. Sci. 71:239-246.

Linville, R. C., D. Pomp, R. K. Johnson, and M. F. Rothschild. 2001. Candidate gene analysis for loci affecting litter size and ovulation rate in swine. J. Anim. Sci. 79:60-67.

Minami, N., K. Sasaki, A. Aizawa, M. Miyamoto, and H. Imai. 2001. Analysis of gene expression in mouse 2-cell embryos using fluorescein differential display: comparison of culture environments. Biol. Reprod. 64:30-35.

Moore, R. W., H. E. Redmond, and C. W. Livingston, Jr. 1965. Iron deficiency anemia as a cause of stillbirths in swine. J. Am. Vet. Med. Assoc. 147:746-748.

Oppenheim, E. W., C. Adelman, X. Liu, and P. J. Stover. 2001. Heavy chain ferritin enhances serine hydroxymethyltransferase expression and de novo thymidine biosynthesis. J. Biol. Chem. 276:19855-19861.

Robert, C., D. Gagne, D. Bousquet, F. L. Barnes, and M. A. Sirard. 2001. Differential display and suppressive subtractive hybridization used to identify granulosa cell messenger RNA associated with bovine oocyte developmental competence. Biol. Reprod. 64:1812-1820.

Rohrer, G. A., T. H. Wise, D. D. Lunstra, and J. J. Ford. 2001. Identification of genomic regions controlling plasma FSH concentrations in Meishan-White Composite boars. Physiol. Genomics 6:145-151.

Schadt, E. E., S. A. Monks, T. A. Drake, A. J. Lusis, N. Che, V. Colinayo, T. G. Ruff, S. B. Milligan, J. R. Lamb, G. Cavet, P. S. Linsley, M. Mao, R. B. Stoughton, and S. H. Friend. 2003a. Genetics of gene expression surveyed in maize, mouse and man. Nature 422:297-302.

Schadt, E. E., S. A. Monks, and S. H. Friend. 2003b. A new paradigm for drug discovery: integrating clinical, genetic, genomic and molecular phenotype data to identify drug targets. Biochem. Soc. Trans. 31:437-443. 
Schneyer A., A. Schoen, A. Quigg, and Y. Sidis. 2003. Differential binding and neutralization of activins $\mathrm{A}$ and $\mathrm{B}$ by follistatin and follistatin like-3 (FSTL-3/FSRP/FLRG). Endocrinology 144: 1671-1674.

White, K., and H. N. Munro. 1988. Induction of ferritin subunit synthesis by iron is regulated at both the transcriptional and translational levels. J. Biol. Chem. 263: 8938-8942.

Wise, T., D. D. Lunstra, G. A. Rohrer, and J. J. Ford. 2003. Relationships of testicular iron and ferritin concentrations with testicular weight and sperm production in boars. J. Anim. Sci. 81:503-511.
Xu, B., L. Lin, and N. S. Rote. 1999. Identification of a stress-induced protein during human trophoblast differentiation by differential display analysis. Biol. Reprod. 61:681-686.

Zhou, X. Y., S. Tomatsu, R. E. Fleming, S. Parkkila, A. Waheed, J. Jiang, Y. Fei, E. M. Brunt, D. A. Ruddy, C. E. Prass, R. C. Schatzman, R. O'Neill, R. S. Britton, B. R. Bacon, and W. S. Sly. 1998. HFE gene knockout produces mouse model of hereditary hemochromatosis. Proc. Natl. Acad. Sci. USA 95:2492-2497.

Zhu, L. J., M. K. Bagchi, and I. C. Bagchi. 1995. Ferritin heavy chain is a progesterone-inducible marker in the uterus during pregnancy. Endocrinology 136:4106-4115. 